\title{
Analisis Penyuluhan dan Keberdayaan Petani Karet Pola Swadaya di Kabupaten Rokan Hilir, Provinsi Riau
}

\section{An Analysis of Extension and Empowerment of Independent Rubber Farmers in Rokan Hilir Regency}

\author{
Rosnita $^{1}$, Eri Sayamar ${ }^{2}$, Sergius Septian Sianturi ${ }^{3}$, Roza Yulid ${ }^{4}$, Eben K.P. Simanjuntak ${ }^{5}$ \\ ${ }^{1,2,4}$ Dosen Jurusan Agribisnis Fakultas Pertanian Universitas Riau, Riau \\ ${ }^{3,5}$ Alumni Jurusan Agribisnis Fakultas Pertanian Universitas Riau, Riau
}

\begin{abstract}
The objectives of this study were (1) to describe the role of extension for independent/small-holder farmers of rubber (2) to describe the empowerment level of the farmers, (3) to describe the goal of extension, (4) to analyze the effect of extension on empowerment, (5) to determine the effect of empowerment on the goal of extension. This study was conducted in the Districts of Pujud and Tanah Putih in Rokan Hilir Regency. The study respondents consisting of 118 respondents were determined by a simple random sampling method. To answer the first, second, and third objective, this study used the likert's scale summated rating (SLR). To answer the fourth and fifth objective, this study used the structural equation modeling (SEM). The result showed (1) extension had an edaquate effect on the independent/ small holder rubber farmers, (2) The empowerment level of farmers is categorized as already good, (3 ) the goal of extension has been reached as seen from better farming, better business and better living, (4) the role of extension has a significant effect on the level of farmer's empowerment; (5) the level of farmer's empowerment has a significant effect on the achieved goal of extension.
\end{abstract}

Keywords : extension, empowerments, farmers, rubber

\begin{abstract}
Abstrak
Penelitian ini bertujuan (1) mendeskripsikan peran penyuluhan terhadap petani karet pola swadaya; (2) mendeskripsikan tingkat keberdayaan petani; (3) mendeskripsikan tingkat ketercapaian tujuan penyuluhan; (4) menganalisis pengaruh peran penyuluhan terhadap keberdayaan; (5) menganalisis pengaruh keberdayaan terhadap ketercapaian tujuan penyuluhan. Penelitian ini dilaksanakan di Kecamatan Pujud dan Kecamatan Tanah Putih Kabupaten Rokan Hilir. Responden penelitian ditentukan menggunakan metode key informan sampling dengan jumlah responden sebanyak 118. Untuk menjawab tujuan pertama, kedua, dan ketiga dari penelitian ini menggunakan likert's scale summated rating (SLR). Untuk menjawab tujuan keempat dan kelima menggunakan structural equation modeling (SEM) dengan program AMOS. Hasil penelitian menunjukkan bahwa (1) peran penyuluhan cukup berperan terhadap usaha tani petani karet pola swadaya; (2) tingkat keberdayaan petani di kategorikan berdaya; (3) tujuan penyuluhan telah tercapai yang dilihat dari better farming, better business, dan better living; (4) peran penyuluhan terbukti berpengaruh secara signifikan terhadap tingkat keberdayaan petani; (5) tingkat keberdayaan petani terbukti berpengaruh signifikan terhadap tercapainya tujuan penyuluhan.
\end{abstract}

Kata kunci : penyuluhan, keberdayaan, petani, karet

\section{Pendahuluan}

Indonesia merupakan negara yang memiliki potensi perekonomian di sektor pertanian. Selain penyumbang devisa negara, pertanian juga membuka peluang usaha atau sebagai tenaga kerja bagi masyarakat di Indonesia. Kontribusi sektor pertanian terhadap PDB Indonesia tahun 2011 hingga 2014 sebesar 13,41\%. Besarnya kontribusi sektor pertanian terhadap pembangunan ekonomi nasional didorong pertumbuhan dan perkembangan dari subsektor perkebunan. Salah satu komoditi hasil perkebunan yang mempunyai peran cukup penting dalam kegiatan perekonomian di Indonesia adalah tanaman karet.

Provinsi Riau merupakan salah satu penghasil karet terbesar dengan jumlah produksi hingga
367.261 ton dan luas lahan sebesar 502.906 ha. Sebagian besar perkebunan karet yang ada di Riau dimiliki oleh petani swadaya, yang diusahakan hanya dalam skala kecil, berbeda halnya dengan perkebunan karet yang dimiliki oleh pemerintah ataupun pihak swasta. Pengusahaannya dilakukan dalam skala besar dengan sistem teknologi modern. Kabupaten Rokan Hilir merupakan salah satu daerah penghasil karet d Provinsi Riau dengan luas lahan 26.359 ha dan produksi sebesar 23.990 ton sehingga produktivitas karet di Kabupaten Rokan Hilir sebesar 0,91 ton/ha (Dinas Perkebunan Provinsi Riau, 2014).

Produktivitas perkebunan karet rakyat di Provinsi Riau sebesar 1,086 ton/ha sehingga tidak berbanding lurus dengan perusahaan negara yang memiliki produktivitas sebesar 1,582 ton/ha dan

\footnotetext{
${ }^{1}$ Korespondensi penulis

E-mail: rosnitamag@gmail.com
} 
swasta sebesar 1,721 ton/ha. Kondisi perkebunan karet di Provinsi Riau menggambarkan adanya ketimpangan yang sangat jauh antara produktivitas karet milik rakyat dan milik Negara serta Swasta. Jika menggunakan bibit unggul, setidaknya petani bisa memperoleh produktivitas karet 1,136 ton/Ha (Budiman, 2012).

Rendahnya produktivitas yang mampu dicapai oleh petani rakyat diduga disebabkan oleh berbagai hal seperti mutu SDM petani yang rendah, kurang berperannya kegiatan penyuluhan yang dilakukan oleh penyuluh selaku pendamping dalam membina petani, ketidakberdayaan petani dalam menerapkan apa yang disarankan oleh penyuluh dengan kondisi sosial ekonomi dan pendidikan petani, sehingga mengakibatkan kegiatan penyuluhan yang dilakukan penyuluh belum mampu memberdayakan petani. Akhirnya tujuan dari kegiatan penyuluhan agar petani mampu bertani dengan lebih baik (better farming), dan petani mampu melakukan bisnis usahataninya dengan lebih baik (better business) yang akan mampu mengantarkan kehidupan petani menjadi lebih sejahtera (better living) belum mampu dicapai.

Dalam berusahatani tanaman karet faktorfaktor produksi yang baik sangat dibutuhkan seperti pada tahap persiapan yang meliputi: penyiapan bibit, penanaman, pemeliharaan, dan pemanenan sampai kepada pemasaran, akan tetapi kegiatan tersebut masih berlangsung secara alami yang dilakukan oleh petani, artinya penyuluh sebagai pendamping masyarakat belum dapat menjalankan perannya sebagai agen yang dapat mewujudkan keberdayaan petani agar mencapai produksi yang optimal. Soedijanto, 2003 mengatakan bahwa mutu SDM petani akan dapat mendukung pembangunan pertanian kini dan masa datang manakala penyuluhan pertanian merupakan proses pemberdayaan, bukan proses transfer teknologi (Sadono, 2008). Perlu dikaji apakah penyuluh sebagai agen dalam mewujudkan pemberdayaan petani karet di Kabupaten Rokan Hilir belum berhasil melaksanakan perannya dalam memberdayakan petani ?. Hasil penelitian di Desa Rasi Kecamatan Ratahan Kabupaten Minahasa mengungkapkan bahwa persepsi petani sangat baik terhadap peran penyuluh terutama dalam inovasi dan peningkatan produktivitas (Timbulus et al., 2016).

Kegiatan penyuluhan yang dilakukan oleh penyuluh hendaknya mampu meningkatkan partisipasi petani, oleh karena itu dituntut penyuluh untuk mampu memberdayakan petani dalam proses penyuluhan yang mana petani ikut terlibat dalam mengambil keputusan baik dalam merencanakan, melaksanakan dan juga mengevaluasi apa yang telah dilaksanakan. Dengan demikian kegiatan penyuluhan yang dilakukan akan sesuai dengan kebutuhan petani dengan melibatkan petani dalam merencanakan kegiatan sehingga akan berdampak kepada kemampuan atau keberdayaan petani dan tercapainya tujuan penyuluhan. Hal tersebut sesuai dengan ungkapan Sangaji, 2011 bahwa strategi yang dapat dilakukan untuk meningkatkan partisipasi masyarakat adalah memperbaiki proses penyuluhan yang partisipatif.

Dengan demikian memunculkan beberapa pertanyaan: (1) Peran penyuluhan apa saja yang telah dijalankan dalam kegiatan usahatani karet di Kabupaten Rokan Hilir? (2) Bagaimana tingkat keberdayaan petani karet di Kabupaten Rokan Hilir? (3) Bagaimana tingkat ketercapaian tujuan penyuluhan dilihat dari better farming, better business, dan better living di Kabupaten Rokan Hilir? (4) Bagaimana pengaruh peran penyuluhan terhadap tingkat keberdayaan petani karet rakyat di Kabupaten Rokan Hilir? (5) Bagaimana pengaruh tingkat keberdayaan petani terhadap tercapainya tujuan penyuluhan yang dilihat dari better farming, better business, dan better living di Kabupaten Rokan Hilir?. Berdasarkan uraian diatas mengantar penulis untuk perlu melakukan penelitian yang terkait dengan pelaksanaan penyuluhan dan keberdayaan petani karet di Kabupaten Rokan Hilir

Penelitian ini bertujuan untuk: (1) Untuk mendeskripsikan peran penyuluhan terhadap petani karet di Kabupaten Rokan Hilir. (2) Untuk mendeskripsikan tingkat keberdayaan petani karet di Kabupaten Rokan Hilir. (3) Mendeskripsikan tingkat ketercapaian tujuan penyuluhan yang dilihat dari better farming, better business, dan better living di Kabupaten Rokan Hilir. (4) Menganalisis pengaruh peran penyuluh terhadap tingkat keberdayaan petani karet rakyat di Kabupaten Rokan Hilir. (5) Menganalisis pengaruh tingkat keberdayaan petani terhadap tercapainya tujuan penyuluhan yang dilihat dari better farming, better business, dan better living di Kabupaten Rokan Hilir.

\section{Metode Penelitian}

Penelitian tentang analisis penyuluhan dan keberdayaan petani karet pola swadaya di Kabupaten Rokan Hilir dilaksanakan pada bulan Januari- 
Agustus 2016. Lokasi penelitian yaitu di Kecamatan Pujud dan Kecamatan Tanah Putih Kabupaten Rokan Hilir. Pemilihan lokasi didasarkan bahwa Kabupaten Rokan Hilir merupakan satu-satunya Kabupaten yang belum menerapkan Undang-Undang Penyuluhan No. 16 tahun 2006, bahwa satu penyuluh untuk satu yang polivalen.

Pengambilan sampel dilakukan secara sengaja terhadap petani karet pola swadaya yang berada di Kabupaten Rokan Hilir, tepatnya di Kecamatan Pujud dan Kecamatan Tanah Putih. Untuk penentuan responden digunakan key informan yaitu penyuluh perkebunan di Kecamatan Pujud dan Kecamatan Tanah Putih. Data key informan digunakan sebagai informasi terbuka dari penyuluh dan konfirmasi terhadap data yang dianalisis. Jumlah sampel sebanyak 118 orang petani karet yang mengikuti kegiatan penyuluhan dengan aktif dan memiliki kelompoktani.

Jenis data yang dikumpulkan adalah: (1) Data primer yakni data yang diperoleh dengan melakukan wawancara langsung kepada informan dan isian kuesioner oleh responden berupa data peran penyuluhan yaitu edukasi, diseminasi, fasilitasi, konsultasi, supervisi, monitoring dan evaluasi; keberdayaan petani yaitu keberdayaan SDM, ekonomi produktif dan kelembagaan, dan tujuan penyuluhan yang diukur dari better farming, better business dan better living; (2) Data sekunder yaitu data yang diperoleh dari instansi yang berkaitan langsung, seperti: Dinas Perkebunan dan kehutanan Kabupaten Rokan Hilir. Data yang diperlukan adalah data luas dan produksi karet Kabupaten Rokan Hilir.

Teknik pengumpulan data dilakukan dengan cara sebagai berikut: (1) Teknik Observasi yaitu teknik pengumpulan data yang dilakukan dengan mengadakan pengamatan langsung pada objek yang diteliti; (2) Kuesioner yaitu teknik pengumpulan data dengan menyebarkan daftar pertanyaan kepada responden; (3) Teknik wawancara yaitu pengumpulan data yang diperoleh dengan bertanya langsung kepada informan menggunakan daftar pertanyaan tertulis, data yang diperoleh dipergunakan sebagai data primer; dan (4) Teknik pencatatan yaitu mencatat data yang diperlukan dari instansi terkait yang berhubungan dengan penelitian ini.

Peran penyuluhan, tingkat keberdayaan dan tujuan penyuluhan dianalisis dengan metode Skala Likert's Summated Rating (SLR). Skala likert digunakan untuk mengukur sikap, pendapat dan persepsi seseorang atau sekelompok tentang kejadian atau gejala sosial (Sugiyono, 2006). Nilai-nilai jawaban tertutup dari responden dibuat dalam bentuk pernyataan positif (jawaban yang diharapkan) diberi nilai 5 hingga pernyataan negatif (jawaban yang tidak diharapkan) diberi nilai 1 seperti yang disajikan pada Tabel 1.

Untuk melihat pengaruh peran penyuluhan terhadap keberdayaan dan keberdayaan terhadap tujuan penyuluhan dianalisis dengan menggunakan model Structural Equation Modelling (SEM). Menurut Sugiyono (2007) penggunaan Structural Equation Modelling didasarkan pada beberapa asumsi yaitu: (1) Hubungan antar variabel yang akan dianalisis berbentuk linear, aditif dan kausal. (2) Variabel-variabel residual tidak berkorelasi dengan variabel yang mendahuluinya, dan tidak juga berkorelasi dengan variabel yang lain. (3) Dalam model hubungan variabel hanya terdapat jalur kausal/ sebab akibat searah. (4) Data setiap variabel yang dianalisis adalah data interval dan berasal dari sumber yang sama.

Data yang diperoleh dari responden adalah data dalam bentuk primer dan bersifat ordinal sehingga untuk analisis SEM diperlukan data dengan ukurannya paling tidak interval, maka untuk seluruh

Tabel 1. Nilai Skala Jawaban yang Diberikan Responden (Pernyataan Positif)

\begin{tabular}{llll}
\hline Peran Penyuluhan & Keberdayaan & Tujuan Penyuluhan & Nilai Skala \\
\hline Sangat Berperan & Sangat Berdaya & Sangat Tercapai & 5 \\
Berperan & Berdaya & Tercapai & 4 \\
Cukup Berperan & Cukup Berdaya & Cukup Tercapai & 3 \\
Kurang Berperan & Kurang Berdaya & Kurang Tercapai & 2 \\
Sangat Kurang Berperan & Sangat Kurang Berdaya & Sangat Kurang Tercapai & 1 \\
\hline
\end{tabular}


variabel yang berskala ordinal terlebih dahulu ditransformasihkan tingkat pengukurannya ke tingkat interval melalui Method of Succesive Interval (MSI) dengan langkah-langkah sebagai berikut (Harun Al Rasyid, 1994 dalam Rosnita, 2011) : (1) Menghitung frekuensi responden yang memberikan respon untuk setiap nilai (1 sampai dengan 5). (2) Menghitung frekuensi kumulatif yaitu dengan menjumlahkan terus dari setiap nilai. (3) Menentukan proporsi kumulatif dengan cara membagi frekuensi kumulatif dengan total frekuensi. Proporsi kumulatif dianggap mengikuti distribusi normal baku. (4) Menghitung nilai $\mathrm{z}$ berdasarkan pada proporsi kumulatif diatas. (5) Dari nilai $\mathrm{z}$ yang diperoleh ditentukan nilai densitynya (nilai ordinal dari sebaran normal z dengan menggunakan tabel) (6) Menentukan nilai skala SV (Scala Value) (Sudradjat, 2002) dengan rumus:

$\mathrm{SV}=$

(Density at Lower Limit) - (Density at Upper Limit)

(Area Under Upper Limit) - (Area Under Lower Limit)

SV yang nilainya terkecil (harga negatif yang terbesar) diubah menjadi sama dengan 1 (satu). (7) Aplikasi Microsoft office excel 2007 digunakan dalam proses penghitungan.

Pengujian asumsi SEM yang perlu dilakukan adalah sebagai berikut: (1) Uji Validitas dan Reabilitas Data; (2) Uji Outliers; (3) Uji Normalitas data; (4) Multicollinearity dan Singularity

Adapun langkah permodelan Structural Equation Modeling sebagai berikut: (Ghozali, 2004) (1) Pengembangan Model Berdasarkan Teori; (2) dan (3) Menyusun Diagram Alur dan Persamaan struktural; (4) Memilih Jenis Input Matrik dan Estimasi Model yang Diusulkan; (5) Menilai Identifikasi Model Struktural; (6) Menilai Kriteria Goodness of Fit Full Structural Equation Modelling (SEM)

Hipotesis pada penelitian adalah: (1) Terdapat pengaruh yang signifikan peran penyuluhan yang meliputi edukasi, diseminasi, fasilitasi, konsultasi, supervisi, monitoring dan evaluasi terhadap keberdayaan petani karet pola swadaya di Kabupaten Rokan Hilir dan (2) Terdapat pengaruh yang signifikan tingkat keberdayaan petani terhadap tercapainya tujuan penyuluhan yang meliputi better farming, better business, better living di Kabupaten Rokan Hilir.

\section{Hasil dan Pembahasan}

\section{Usahatani Karet}

Usahatani karet merupakan kegiatan usaha yang dilakukan petani turun temurun dijalani oleh keluarga. Menurut cerita tanaman karet asal mulanya dibawa oleh pedagang cina atau kaum muslim yang menunaikan ibadah haji dan mampir di malaysia karena tanaman ini telah berkembang di malaysia. Riau adalah penghasil karet ketiga di sumatera setelah Sumatera Utara dan Jambi. Tahun 2004, luas perkebunan karet rakyat mencapai 359.091 ha (12,97\% dari karet rakyat Indonesia). Petani karet swadaya rata-rata memiliki luas usahatani karetnya 1 ha dengan pengelolaan yang sangat sederhana. Dalam aspek budidaya petani dalam mempersiapkan lahan untuk kebun karet umumnya dengan membuka lahan secara tradisional dengan melakukan penebangan dan membakar. Cara ini dianggap menggunakan biaya yang murah, menggunakan bibit yang dominan bibit lokal, dimana setelah bibit ditanam dibiarkan begitu saja tanpa perawatan. Pemupukan dilakukan sesuai dengan kemampuan petani. Terdapat beberapa petani yang menanam karet bersamaan dengan tanaman lainnya seperti jengkol, petai, nangka atau tanaman kayu seperti meranti. Penyadapan dilakukan petani setiap hari pada pagi hari dan juga tergantung pada cuaca dengan pengumpulan hasil sadapan tiap 3 hari sekali. Petani menjual hasil panennya umumnya kepada toke di tingkat desa atau dikenal dengan tengkulak dengan harga jual rata-rata berkisar antara Rp 7.000 sampai Rp 8.000/kg. Ojol yang dihasilkan sekitar 3,777 ton/ha/thn dengan total biaya Rp. 3,456 juta/ha/thn. Pada beberapa kabupaten di Provinsi Riau seperti Kecamatan Gunung Toar Kabupaten Kuantan Singingi petani yang sudah tergabung dalam kelompoktani atau Gabungan Kelompoktani (Gapoktan) melakukan pemasaran karet dengan sistem lelang dimana harga yang diterima petani sudah lebih baik yakni Rp 10.000/kg sedangkan harga karet dunia sudah mencapai Rp 16.200/kg.

\section{Peran Penyuluhan terhadap Petani Karet}

Petani karet sebagai pelaku utama dalam kegiatan usahanya ikut berperan dalam rangka pembangunan pertanian di Indonesia. Selaku ujung tombak terdepan dalam kegiatan usahatani karetnya 
yang masih tradisional tentunya petani membutuhkan penyuluh selaku pendamping petani dalam kegiatan usahatani yang dijalankan. Mardikanto (2009) mengungkapkan bahwa penyuluh memiliki peran dalam membina petani yakni: edukasi, diseminasi, fasilitasi, konsultasi, supervisi, monitoring dan evaluasi. Hasil analisis menggambarkan bahwa berdasarkan persepsi petani karet, secara rerata penyuluh baru mampu "cukup berperan" dalam membina petani karet sesuai dengan tujuan dari kegiatan penyuluhan pada petani karet agar petani mampu bertani dan berbisnis karet dengan lebih baik sehingga pendapatan petani mampu meningkat dan petani dapat hidup dengan lebih sejahtera. Hal tersebut ditunjukkan dengan nilai skor sebesar 2,85 (Tabel 2) dari rata-rata peran yang sudah dijalankan

Tabel 2. Peran Penyuluhan pada Petani Karet di Kabupaten Rokan Hilir, 2016

\begin{tabular}{|c|c|c|}
\hline \multirow{2}{*}{ Variabel dan Indikator } & Nilai & \multirow{2}{*}{ Kategori } \\
\hline & Skala & \\
\hline Edukasi (ED) & 2,61 & Cukup Berperan \\
\hline $\begin{array}{l}\text { Relevansi materi program penyuluhan } \\
\text { Arahan dalam usaha tani karet } \\
\text { Pengetahuan Petani karet meningkat } \\
\text { Keterampilan petani meningkat } \\
\text { Jumlah pertemuan/penyuluhan }\end{array}$ & $\begin{array}{l}2,37 \\
2,50 \\
2,97 \\
2,53 \\
2,69\end{array}$ & $\begin{array}{l}\text { Kurang Berperan } \\
\text { Kurang Berperan } \\
\text { Cukup Berperan } \\
\text { Kurang Berperan } \\
\text { Cukup Berperan }\end{array}$ \\
\hline Diseminasi (DI) & 2,86 & Cukup Berperan \\
\hline Membawa informasi atau inovasi & 2,86 & Cukup Berperan \\
\hline Petani lain yang tidak mendapatkan penyuluhan & 2,34 & Kurang Berperan \\
\hline Informasi yang sesuai dengan keadaan masyarakat setempat & 2,61 & Cukup Berperan \\
\hline Menyampaikan informasi harga saprodi dan produksi & 2,78 & Cukup Berperan \\
\hline Fasilitasi (FA) & 2,76 & Cukup Berperan \\
\hline Memfasilitasi setiap keluhan / masalah petani & 3,06 & Cukup Berperan \\
\hline Memfasilitasi pengembangan motivasi atau minat & 2,43 & Kurang Berperan \\
\hline Memfasilitasi petani untuk bermitra dengan lembaga lain. & 2,71 & Cukup Berperan \\
\hline Memfasilitasi petani untuk memasarkan hasil usaha tani & 2,85 & Cukup Berperan \\
\hline Konsultasi (KO) & 2,97 & Cukup Berperan \\
\hline Memberikan sarana konsultasi ke setiap kelompok & 2,82 & Cukup Berperan \\
\hline Memberikan cara konsultasi yang baik & 3,10 & Cukup Berperan \\
\hline \multicolumn{3}{|l|}{ Memberikan waktu kepada petani untuk melakukan } \\
\hline Konsultasi & 2,98 & Cukup Berperan \\
\hline Supervisi (SU) & 3,11 & Cukup Berperan \\
\hline Pembinaan terhadap kemampuan teknik petani & 3,17 & Cukup Berperan \\
\hline \multicolumn{3}{|l|}{ Pembinaan terhadap petani dalam pemasaran hasil } \\
\hline Usahatani & 2,80 & Cukup Berperan \\
\hline Pembinaan untuk memanfaatkan sumber daya alam & 3,49 & Berperan \\
\hline Pembinaan untuk memanfaatkan sumber daya manusia & 2,98 & Cukup Berperan \\
\hline Monitoring dan Evaluasi (MO) & 2,80 & Cukup Berperan \\
\hline Monitoring dan evaluasi terhadap usahatani & 3,24 & Cukup Berperan \\
\hline Monitoring dan evaluasi terhadap pemanfaatan teknologi & 2,53 & Cukup Berperan \\
\hline Evaluasi terhadap kegiatan penyuluh & 2,67 & Cukup Berperan \\
\hline Evaluasi terhadap peningkatan keterampilan dan pendapatan petani & 2,78 & Cukup Berperan \\
\hline Peran Penyuluhan $(\mathrm{X})$ & 2,85 & Cukup Berperan \\
\hline
\end{tabular}


penyuluh.

Dalam proses edukasi terhadap petani karet yang dijalankan oleh penyuluh, petani karet merasa penyuluh belum mampu berperan akan tetapi baru mampu untuk "cukup berperan" dalam meningkatkan pengetahuan petani, karena Kabupaten Rokan Hilir dalam pelaksanaan penyuluhan belum mengadopsi atau melaksanakan Undang Undang No. 12 Tahun 2006, dimana penyuluh belum polivalen sehingga penyuluh yang bertugas memberikan penyuluhan adalah penyuluh tanaman pangan.

Penyuluh perkebunan akan mengunjungi petani ketika itu terkait dengan program dinas perkebunan atau kehadirannya diminta oleh BPP. Kondisi ini mengakibatkan kegiatan penyuluhan lebih kepada penyuluhan pangan. Kekurangan yang dirasakan petani adalah materi yang disampaikan masih memiliki relevansi yang kurang dengan kebutuhan petani dan permasalahan yang dihadapi oleh petani, penyuluh kurang memberikan arahan kepada petani bagaimana seharusnya petani mengelola dan mengembangkan usahatani karet yang dijalankan petani, sehingga petani merasa keterampilan petani kurang meningkat dari kegiatan penyuluhan yang ada. Persepsi petani terhadap peran edukasi yang dilakukan penyuluh masih dirasakan "kurang berperan" terutama dalam relevansi materi, arahan dalam melakukan usahatani dan keterampilan petani dalam menjalankan usahatani karet masih belum meningkat. Kegiatan di lapangan, penyuluh dalam menyampaikan materi masih mengacu kepada program yang berorientasi kepada kebijakan dan belum kepada kebutuhan petani. Hal ini sama dengan hasil penelitian Indraningsih (2011) tentang persepsi petani terhadap kesesuaian materi dalam proses adopsi teknologi pertanian terpadu bahwa persepsi petani adopter $(73,7 \%)$ dan non adopter $(70,9 \%)$ terhadap materi penyuluhan masih termasuk dalam katagori sedang.

Penyuluh dalam mendistribusikan informasi masih kurang dirasakan petani, persepsi petani bahwa penyuluhan baru sebatas "cukup berperan" dalam distribusi informasi. Beberapa informasi yang dibutuhkan petani seperti tentang harga karet, teknologi-teknologi baru dalam proses pengolahan karet menjadi ojol atau sheet, sistem dan rantai pemasaran dan harga masih sangat terbatas dimana petani masih tergantung kepada toke atau tengkulak. Penyuluhan yang sudah dijalankan penyuluh tersebut menurut petani karet masih berada pada katagori cukup, karena informasi sangat terbatas tersebar kepada petani yang ikut pada kegiatan penyuluhan sementara penyebaran informasi kepada petani lain yang tidak mendapatkan kegiatan penyuluhan masih dirasakan kurang.

Hal tersebut membuat petani merasa bahwa penyuluh baru sebatas "cukup berperan" dengan nilai skor 2,86 dan diseminasi pada petani yang tidak terlibat pada kegiatan penyuluhan masih dirasakan "kurang berperan" dengan nilai skor 2,34. Agar petani merasa bahwa penyuluhan sangat berperan dalam memberdayakan petani, maka peran yang harus dijalankan penyuluh tidak hanya sekadar menyampaikan dan mendistribusikan informasi akan tetapi juga harus mampu menggerakkan dan memotivasi, mendidik, dan menjadi tempat untuk berkonsultasi bagi petani. Hal tersebut sesuai dengan ungkapan Tjiptopranoto (2003) dan Subejo (2009) bahwa peran Penyuluh Pertanian dituntut tidak hanya sekedar sebagai penyampai (desiminator) teknologi dan informasi, akan tetapi juga sebagai motivator, dinamisator, pendidik, fasilitator, dan konsultasi bagi petani (Indraningsih, 2011).

Penyuluh dalam memfasilitasi petani untuk mengatasi setiap keluhan yang dihadapi, memfasilitasi agar petani bermitra dengan lembaga lain atau memfasilitasi agar dalam memasarkan hasil usahatani masih belum dirasakan petani dan berada dalam katagori "cukup berperan" yang ditunjukkan dengan rata-rata skor 2,76 , terutama memfasilitasi dalam memotivasi atau mengembangkan minat petani untuk melakukan agribisnis karet dengan lebih baik masih dirasakan "kurang berperan" yang ditunjukkan dengan nilai skor 2,43. Hal ini terjadi karena penyuluh yang bertugas di lokasi penelitian (penyuluh pangan) bukan penyuluh yang polivalen sesuai dengan (UU No.16 Tahun 2006), sehingga kemampuan penyuluh masih terbatas dalam membantu petani untuk mendapatkan harga karet yang baik dan relatif stabil, harga karet yang cenderung tidak mengalami perubahan dibandingkan dengan harga sawit yang selalu lebih baik, sehingga petani lebih termotivasi untuk mengembangkan usaha dengan menambah cabang usahanya selain usahatani karet seperti usahatani kelapa sawit, berdagang atau beternak dan kurang termotivasi dalam mengembangkan skala usaha pada usahatani karet.

Peran penyuluh sebagai konsultasi diperoleh nilai 2,97 dengan kategori cukup berperan, artinya penyuluh belum berperan secara maksimal dalam 
melayani petani untuk melakukan konsultasi dalam pemecahan masalah yang dihadapi petani karet. Kondisi ini membuat petani tidak termotivasi untuk mengembangkan usahatani karetnya, akan tetapi mereka lebih senang mengembangkan usahatani kelapa sawit karena menurut petani kelapa sawit lebih menjanjikan dibanding karet

Penyuluh telah melakukan pembinaan kepada petani terutama dalam bagaimana petani memanfaatkan sumberdaya alam yang ada. Petani karet merasakan bahwa peran penyuluh masih terbatas dan dirasakan kurang sehingga yang dirasakan petani peran penyuluh baru berada pada level yang "cukup berperan" dalam melakukan pembinaan terhadap petani yang ditunjukkan dengan nilai skor 3,11. Pembinaan terhadap pemasaran karet masih memperoleh skor yang lebih rendah dengan skor 2,80 karena penyuluh belum mampu berperan dalam menaikkan harga karet, harga karet berkisar Rp 7.000/kg sampai Rp 8.000/kg dimana pada saat yang sama harga karet di tingkat dunia pada saat itu mencapai Rp 16.300. Menurut petani harga yang layak mereka terima minimal Rp 13.200/kg ojol.

Monitoring dan evaluasi merupakan kegiatan penyuluhan yang harus tetap dijalankan oleh penyuluh, karena tanpa itu semua penyuluh tidak akan mengetahui apakah kegiatan yang telah dilaksanakan sudah mampu memberdayakan petani dan mencapai tujuan kegiatan penyuluhan yang diharapkan sebagaimana mestinya pada petani karet. Monitoring dan evaluasi yang dijalankan oleh penyuluh terutama dalam mengevaluasi apakah petani menjalankan kegiatan usahatani sesuai dengan apa yang disarankan penyuluh pada proses edukasi, apakah terjadi peningkatan keterampilan dan pendapatan petani dengan terlibatnya petani dalam kegiatan penyuluhan. Monitoring yang belum aktif dilakukan penyuluh terutama terhadap kemampuan petani dalam memanfaatkan teknologi yang disarankan, menurut petani monitoring dan evaluasi yang dilaksanakan berada pada katagori "cukup berperan" dengan nilai skor 2,80, peran tertinggi yang dilaksanakan penyuluh ada pada monitoring usahatani karet petani dengan skor 3,24 dan terendah pada kegiatan pemanfaatan teknologi dengan skor 2,53.

\section{Keberdayaan Petani Karet}

Pemberdayaan adalah suatu upaya untuk membangun daya itu sendiri, dengan mendorong, memotivasi dan membangkitkan kesadaran akan potensi yang dimilikinya serta berupaya untuk mengembangkannya. Selanjutnya upaya tersebut diikuti dengan memperkuat potensi atau daya yang dimiliki oleh masyarakat itu sendiri. Pemberdayaan bertujuan dua arah. Pertama, melepaskan belenggu kemiskinan, dan juga keterbelakangan. Kedua, memperkuat posisi lapisan masyarakat dalam struktur ekonomi dan kekuasaan (Mardikanto, 2012).

Slamet (2000) dalam Mardikanto (2009) mengungkapkan bahwa inti dari kegiatan penyuluhan adalah untuk memberdayakan masyarakat. Dengan keberdayaan (SDM, Ekonomi, dan Kelembagaan) yang dimiliki sesuai dengan TKP3KPK (2004) diharapkan masyarakat dapat meningkatkan kesejahteraannya atau keluar dari kemiskinan yang dihadapi. Tingkat keberdayaan petani disajikan pada Tabel 3.

Peran penyululah yang sudah dijalankan dalam memberdayakan petani masih belum dirasakan petani dengan katagori "cukup berperan" dengan nilai skor 3,48. Keberdayaan sumberdaya manusia petani karet dirasakan petani lebih rendah jika dibanding keberdayaan ekonomi dan keberdayaan kelembagaan. Peran penyuluhan yang dirasakan baru pada level "cukup berperan" ternyata belum membuat petani karet "berdaya" dalam menyusun RDKK. Penyusunan RDKK hanya dilakukan oleh orang-orang tertentu. Partisipasi petani dirasakan kurang dalam menyusun RDDK yang harus dipersiapkan petani, biasanya pengurus atau penyuluh yang menyusun RDKK ketika dibutuhkan sebagai salah satu administrasi dalam mendapatkan banntuan. Meskipun demikian secara kelembagaan kelompok sudah memiliki RDK dan RDKK yang disusun pengurus atau penyuluh.

Secara ekonomi, peran penyuluh yang hanya "cukup berperan" menurut petani belum mampu memberdayakan petani dari usahatani karet yang dilakukan. Keberdayaan ekonomi petani karet dengan skor 3,79. Hal yang sangat dirasakan petani karet, keberdayaan mereka dalam meningkatkan pendapatan rumahtangganya tidak sepenuhnya didukung dari usahatani karet, akan tetapi ditunjang dengan usaha lainnya diluar karet yang merupakan usaha sampingan. Usaha sawit yang lebih menjanjikan dibanding karet mendorong petani juga untuk mengembangkan usaha sawit disamping yang lainnya seperti berdagang dan beternak sehingga petani mampu meningkatkan pengeluaran rumah tangga dengan skor 4,58. Hal ini sesuai dengan hasil penelitian Kusning, Sayeti, dan Budihardjo (2011), 
Tabel 3. Keberdayaan Petani Karet

\begin{tabular}{lcl}
\hline \multicolumn{1}{c}{ Variabel } & Nilai skala & Kategori \\
\hline SDM & $\mathbf{2 , 7 8}$ & Cukup Berdaya \\
Pengetahuan petani meningkat & 2,61 & Cukup Berdaya \\
Kompetensi dan kualitas petani meningkat dalam perencanaan bisnis & 2,80 & Cukup Berdaya \\
Partisipasi petani dalam pembuatan RDKK & 2,51 & Kurang Berdaya \\
Petani memiliki rencana usahatani & 3,21 & Cukup Berdaya \\
Ekonomi Produktif (EP) & $\mathbf{3 , 7 9}$ & Berdaya \\
Skala usaha meningkat & 3,60 & Berdaya \\
Pendapatan usahatani meningkat & 3,25 & Cukup Berdaya \\
Peningkatan pendapatan rumah tangga & 3,71 & Berdaya \\
Peningakatan kebutuhan non pangan & 3,82 & Berdaya \\
Meningkatnya pengeluaran rumah tangga setelah adanya penyuluh & 4,58 & Sangat Berdaya \\
Kelembagaan (KE) & $\mathbf{3 , 8 5}$ & Berdaya \\
Lembaga mempunyai tujuan yang jelas & 4,41 & Berdaya \\
Tujuan kelembagaan tercapai & 4,17 & Berdaya \\
Lembaga memiliki struktur yang jelas & 4,12 & Berdaya \\
Kelompoktani mempunyai RDK dan RDKK & 3,50 & Berdaya \\
Terlaksananya RDK dan RDKK & 3,42 & Berdaya \\
Lembaga dapat membantu petani melaksanakan materi usahatani & 2,89 & Cukup Berdaya \\
Kelompoktani menjadi usaha ekonomi Desa & 4,46 & Berdaya \\
Keberdayaan Petani & $\mathbf{3 , 4 8}$ & Berdaya \\
\hline
\end{tabular}

tentang kajian pendapatan petani karet dan kelapa sawit menggambarkan bahwa pendapatan petani kelapa sawit Rp 3.812.250,-/bulan yang lebih besar dari petani karet $\mathrm{Rp} 3.678 .750,-/$ bulan. Keberdayaan terendah dari sisi ekonomi adalah keberdayaan dalam meningkatkan pendapatan dari usahatani karet dengan nilai skor 3,25. Dapat disimpulkan bahwa keberdayaan ekonomi rumahtangga petani karet yang didukung dari usaha diluar karet mampu memenuhi pengeluaran rumahtangga untuk memenuhi kebutuhan baik pangan dan non pangan. Pendapatan guna pemenuhan kebutuhan tersebut diperoleh petani selain dari usahatani karet juga usaha diluar usahatani karet seperti usaha kelapa sawit, dagang dan peternakan. Petani karet belum mampu memberdayakan ekonomi dari usahatani karet, karena menurut petani pendapatan dari usahatani karet kurang mengalami peningkatan.

Keberdayaan kelembagaan dengan nilai skor 3,85 merupakan tingkat keberdayaan yang memiliki skor lebih tinggi dibanding dengan keberdayaan lainnya (SDM dan Ekonomi). Hal tersebut karena meskipun secara individu keberdayaan petani masih rendah akan tetapi secara berkelompok menjadi lebih baik, karena kelompok digerakkan oleh pengurus yang dapat menutupi keterbatasan petani selaku anggota. Kelompok yang ada mampu menjadikan kelompoktani menjadi kelompok usaha ekonomi desa dengan skor 4,46 yang disebut dengan Lembaga Usaha Ekonomi Desa (UED-SP Kecamatan Pujud), yang bergerak pada usaha simpan pinjam dan pemenuhan kebutuhan petani termasuk dalam pemasaran. Hal tersebut didukung oleh pembentukan kelompok yang memiliki tujuan yang jelas dalam pembentukannya agar petani mampu mengembangkan usahanya dan meningkatkan pendapatan termasuk dari usahatani karet. Kemampuan kelembagaan dengan skor terendah adalah kemampuan lembaga agar petani mampu melaksanakan materi yang diterima dari kegiatan penyuluhan, karena materi yang disampaikan bukan kepada pemecahan masalah yang dihadapi petani akan tetapi lebih kepada program pemerintah.

\section{Ketercapaian Tujuan Penyuluhan}

Tujuan kegiatan penyuluhan yang dilaksanakan dikaitkan dengan pendapat Slamet (2003), dimana tujuan penyuluhan diarahkan pada terwujudnya perbaikan teknis bertani (better farming), perbaikan usahatani (better business), serta perbaikan kehidupan 
petani dan masyarakatnya (better living). Apakah peran penyuluh yang sudah berada pada katagori "cukup berperan" menurut persepsi petani sudah mampu membuat petani berdaya akan mampu mencapai tujuan dari kegiatan penyuluhan (Tabel 4).

Kegiatan penyuluhan meskipun hanya "cukup berperan" akan tetapi keberdayaan petani sudah tercapai dengan tambahan usaha diluar usahatani karet. Tujuan penyuluhan yang mampu dicapai dengan skor tertinggi adalah perbaikan usahatani (better business) dengan skor 3,83 dibanding better living dengan skor 3,51 atau better farming yang hanya memiliki skor 3,47. Better business yang dirasakan petani terutama pada usaha di luar usahatani karet karena petani juga mengembangkan usaha kelapa sawit dan berdagang yang menurut petani lebih menjanjikan. Untuk itu dalam berusahatani petani tidak hanya belajar dan menerima materi dari penyuluh, akan tetapi petani mau belajar atau mencari informasi sendiri kepada sesama petani atau sumber informasi lainnya.

Kemampuan dalam perbaikan hidup petani (Better living) dapat dirasakan petani, terlihat dari kemampuan membeli barang yang bersifat tersier seperti kendaraan sepeda motor, mengalokasikan sebagian dana untuk rekreasi, dan kemampuan berobat ke dokter atau Puskesmas untuk menjamin kehidupan yang lebih sehat. Menurut petani dari 14 kebutuhan petani ratarata petani sudah mampu memenuhi 10 kebutuhan dasarnya. Kemampuan yang paling rendah adalah untuk menabung dan investasi guna mengembangkan usaha dengan skor 3,08 dan kemampuan untuk memenuhi kebutuhan pakaian dengan skor 3,25.

Kemampuan teknis berusahatani dengan lebih baik (Better Farming) merupakan kemampuan dengan skor terendah 3,47. Hal tersebut karena materi yang disampaikan dalam kegiatan penyuluhan tidak berdasarkan kepada kebutuhan dan masalah petani akan tetapi lebih kepada program pemerintah, disisi lain penyuluh belum polivalen.

Pengendalian hama dan penyakit pada teknik bertani (better business) sesuai dengan tujuan penyuluhan belum mampu diatasi oleh petani terutama pada penyakit jamur akar putih yang masih dihadapi petani. Kemampuan memenuhi kebutuhan pakaian dan untuk menabung dan investasi masih baru berada pada katagori cukup tercapai, karena kemampuan membeli kebutuhan akan

Tabel 4. Tujuan Penyuluhan

$\begin{array}{lll}\text { Variabel Nilai skala Kategori } & \text { Kala }\end{array}$

Better Farming (BF)

Pengolahan lahan sesuai anjuran

Penggunaan bibit unggul

Penggunaan pupuk sesuai anjuran

Pengendalian hama dan penyakit secara rutin

Peningkatan produksi

Better Bussiness (BB)

Mampu menentukan tempat/pasar untuk menjual hasil panen

Melakukan kemitraan dengan pihak lain

Pengembangkan usaha lain diluar usahatani karet

Kepercayaan lembaga keuangan yang semakin meningkat

\section{Better Living (BL)}

Kemampuan memenuhi kebutuhan pangan

Kemampuan memenuhi kebutuhan pakaian

Kepemilikan rumah layak huni

Kemampuan menjamin kehidupan yang sehat

Kemampuan untuk menabung dan investasi

Kemampuan mengalokasikan dana untuk rekreasi

Kemampuan memiliki barang tersier

Tujuan Penyuluhan
3,47

3,71

3,81

3,70

2,14

4,00

$\mathbf{3 , 8 3}$

3,77

3,88

3,75

3,93

3,51

3,40

3,25

3,53

3,70

3,08

3,76

3,83

3,61

Tercapai
Tercapai
Tercapai
Tercapai
Kurang Tercapai
Tercapai
Tercapai
Tercapai
Tercapai
Tercapai
Tercapai
Tercapai
Tercapai
Cukup Tercapai
Tercapai
Tercapai
Cukup Tercapai
Tercapai
Tercapai
Tercapai


pakaian umumnya hanya dilakukan sekali dalam setahun pada saat menyambut hari besar islam (lebaran) karena mayoritas petani adalah islam. Keterbatasan kemampuan petani dalam menabung, karena pendapatan yang diperoleh baru mampu memenuhi kebutuhan pangan dan non pangan yang masih bersifat pokok atau kebutuhan dasar, petani belum mampu menyisihkan sebagian dari pendapatan untuk diivensitasikan guna meningkatkan atau menambah skala usaha seperti membeli lahan guna menambah luas lahan usahatani karet yang dijalankan.

\section{Pengaruh Peran Penyuluhan terhadap Keberdayaan dan Tujuan Penyuluhan}

Sebelum dilakukan analisis pengaruh, ada beberapa uji asumi yang perlu dilakukan. Pengujian asumsi SEM yang perlu dilakukan adalah uji validitas dan reabilitas data, uji outliers, uji normalitas data, uji multikolinieritas dan singularitas. Berdasarkan uji reabilitas dan validitas (Pearson Correlation) terdapat indikator yang tidak reabel dan valid yaitu penyuluh memfasilitasi petani untuk mengakses lembaga keuangan, penyuluh membantu memecahkan permasalahan petani karet, pemeliharaan tanaman secara rutin, kemampuan memberikan pendidikan, data tersebut selanjutnya dikeluarkan dari analisis.

Uji normalitas data (nilai maximum dan minimum, dan nilai $Z$ score berkisar \pm 3 ). Nilai minimum dan maximum pada standar deviasi bervariasi pada \pm 3 , artinya tidak ditemukan adanya outlier univariate dari penelitian ini.

Uji Outlier Mahalanobis untuk mendeteksi data-data yang bersifat ekstrim (nilai mahalanobis hitung > nilai Chi Square). Nilai maksimum dan nilai minimum, 31,203 dan 7,188 yang berada dibawah 32,000 menunjukkan tidak terjadi outlier multivariate.

Uji normalitas (nilai c.r Skewness diharapkan berkisar $\pm 2,58$ ), memperlihatkan ditemukan angka yang berada diluar $\pm 2,58$ yakni pada indikator kelembagaan (KE) sebesar -3,896, Data tersebut masih bisa digunakan karena nilai c.r 1,629 yang berada pada kisaran $\pm 2,58$, sehingga data tersebut masih bisa diterima untuk dianalisis.

\section{Analisis Structural Equation Modeling (SEM)}

\section{Pengujian Model}

Hubungan yang secara teoritis yang digambarkan ke dalam diagram jalur dimaksudkan untuk melihat hubungan kausal antara variabel eksogen yakni: peran penyuluhan (X yaitu: edukasi, diseminasi, fasilitasi, konsultasi, supervisi, monitoring dan evaluasi), keberdayaan (Y yaitu: sumberdaya manusia, ekonomi produktif, dan kelembagaan) terhadap variabel endogen tujuan penyuluhan ( $\mathrm{Z}$ yaitu: better farming, better business, dan better living). Selanjutnya menyusun diagram alur berdasarkan konsep teori yang sudah digunakan.

Analisis kecocokan model (Goodness of Fit) dari peran penyuluhan terhadap keberdayaan memperlihatkan nilai Chi Square 32,223 < 35,17 (Cut off value $d f 23$ ) dan keberdayaan terhadap tercapainya tujuan penyuluhan dengan Chi Square 15,50 < 15,51(Cut off value df 8) mengindikasikan bahwa model teoritis dan konseptual pada diagram jalur serta didukung oleh data empirik dapat diterima pada taraf nyata $5 \%$.

Pengujian model secara simultan peran penyuluhan terhadap keberdayaan memperlihatkan nilai GFI 0,951 >0,09, CFI 0,981>0,90, RMSA0,059 $<0,08$, dan keberdayaan terhadap tujuan penyuluhan GFI 0,959 > 0,90, CFI 0,966 >0,90, RMSA 0,090 $<0,08$ (marjinal). Evaluasi model menunjukkan bahwa model penelitian telah memenuhi persyaratan kesesuaian model SEM, sehingga model tersebut dapat dinyatakan fit.

Faktor yang diduga mempengaruhi keberdayaan petani yakni peran penyuluhan dengan indikator adukasi, diseminasi, fasilitasi, supervisi, monitoring dan evaluasi. Keberdayaan dengan indikator sumberdaya manusia, ekonomi produktif dan kelembagaan petani diduga mempengaruhi tercapainya tujuan penyuluhan dengan indikator better farming, better business dan better living.

\section{Full Structural Equation Modelling (SEM)}

Melihat pengaruh peran penyuluhan terhadap keberdayaan petani dan tercapainya tujuan penyuluhan secara bersama sama, hasil analisis full Structural Equation Modelling (SEM) dapat dilihat pada Gambar 1.

Gambar 1 menjelaskan hasil kriteria goodness of fit dari model yang dibangun pada penelitian ini, secara keseluruhan menunjukan bahwa model yang dibangun telah fit terhadap data yang digunakan dalam penelitian, nilai chi square 54,455 $<59,30$ 

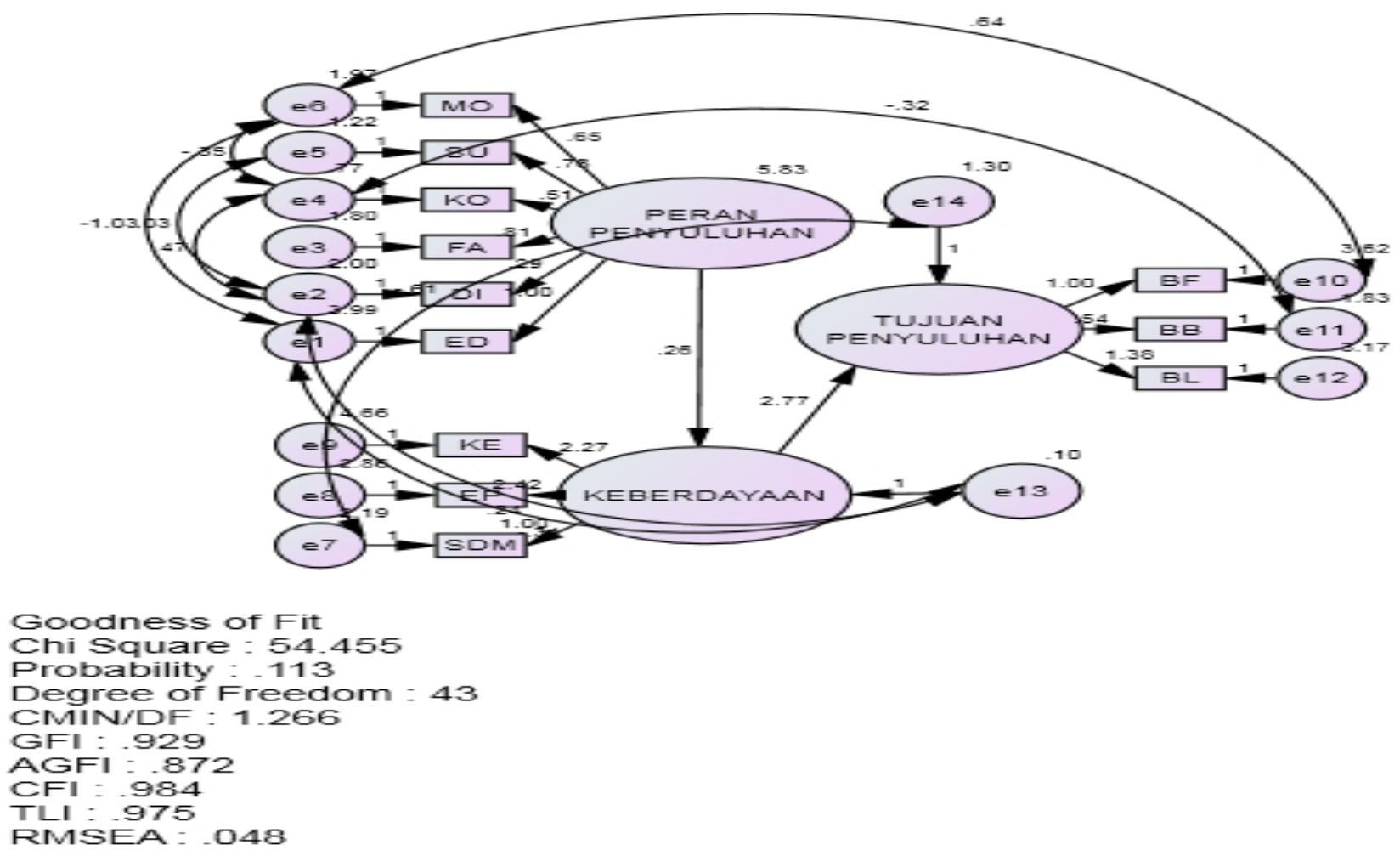

Gambar 1. Full Structural Equation Modelling (SEM)

menunjukan model yang baik, begitupun dengan nilai signifikansi probabilitas, GFI, RMSEA, CMIN/DF, TLI dan CFI yang menunjukan hasil yang baik karena berada pada rentang nilai cut off value. Nilai AGFI diperoleh $0,872<0,90$ berada diluar cut off value dengan kategori marginal, artinya meskipun nilai AGFI belum memenuhi standar kelayakan namun ini masih dapat diterima karena nilai AGFI yang tidak terlalu jauh dari cut off value dan didukung dengan kriteria yang secara keseluruhan baik maka model ini secara keseluruhan sudah fit.

Berdasarkan Gambar 1 dapat dijelaskan bahwa terdapat hubungan antara edukasi sebesar $(1,0)$, diseminasi $(3,99)$, fasilitasi $(2,00)$, konsultasi $(1,80)$, supervisi $(1,7)$, dan monitoring dan evaluasi (1,22). Dengan demikian diseminasi informasi memeliki hubungan yang sangat besar terhadap peran penyuluhan.

Peran penyuluhan berpengaruh terhadap keberdayaan petani karet hanya sebesar 25 persen yang artinya masih terdapat variabel-variabel lain sebesar 75 persen secara konsep teori belum dimasukkan ke dalam model yang turut mempengaruhi keberdayaan petani karet. Kepada peneliti selanjutnya disarankan agar menambahkan variabel lain selain peran penyuluhan ke dalam model yang ikut berpengaruh terhadap keberdayaan petani karet. Dugaan sementara peneliti bahwa disamping peran penyuluhan, maka motivasi, kompetensi dan kemandirian penyuluh ikut berpengaruh terhadap keberdayaan petani karet. Hal ini sesuai dengan hasil kajian Asyiek (2014), bahwa perbedaan kemampuan dalam mengambil keputusan ikut berpengaruh terhadap perbedaan keberdayaan petani.

Hubungan antara sumberdaya manusia (SDM), ekonomi produktif dan kelembagaan masinmasing memiliki hubungan sebesar $(1,00),(2,42)$, dan $(2,47)$ terhadap keberdayaan petani. Kelembagaan memiliki hubungan terbesar terhadap keberdayaan dan SDM dengan hubungan yang terkecil.

Keberdayaan petani karet berpengaruh terhadap tercapainya tujuan penyuluhan hanya sebesar 2,77 persen, yang artinya terdapat 97,23 persen variabel lainnya yang ikut berpengaruh terhadap tercapainya tujuan penyuluhan. Hal tersebut tentunya kepada peneliti selanjutnya hendaknya mencari konsep teori yang menemukan variabel lain yang akan ikut menentukan tercapainya tujuan penyuluhan. Dugaan sementara penulis bahwa kemandirian petani karet dalam (merencanakan, mengambil keputusan, dan melaksanakan) akan ikut mempengaruhi tercapainya tujuan penyuluhan. Hal 
tersebut sesuai dengan pendapat Hatu (2010), bahwa pendampingan sosial merupakan salah satu penentu keberhasilan program pemberdayaan masyarakat (Kusnaini, Muljono, Saleh, 2015).

Hubungan yang terjadi antara better farming, better business, dan better living terhadap tujuan penyuluhan masing-masing sebesar $(1,00),(0,54)$, dan $(1,38)$. Hubungan terbesar adalah better living dan yang terendah better farming. Hal tersebut sejalan dengan analisis likert better farming dengan katagori "tercapai" dan nilai skor 3,51 dan better farming "tercapai” dengan skor 3,47.

\section{Kesimpulan}

1. Penyuluhan baru mampu "Cukup berperan" pada proses edukasi, diseminasi, fasilitasi, konsultasi, dan monitoring dan evaluasi dalam membina petani karet pola swadaya di Kabupaten Rokan Hilir. Peran terbesar yang dilakukan penyuluh adalah supervisi dan terkecil yakni peran edukasi.

2. Keberdayaan yang mampu dicapai petani karet tidak sepenuhnya dari usahatani karet. Usaha lain di luar karet ikut menentukan keberdayaan petani.

3. Better business merupakan tujuan penyuluhan yang terbesar mampu dicapai oleh petani karet dan yang terendah adalah better farming

4. Peran penyuluhan memberikan pengaruh yang sangat signifikan hanya sebesar 25 persen terhadap keberdayaan petani. Terdapat 75 persen variabel lain selain peran penyuluhan yang belum dimasukkan kedalam model yang diduga berpengaruh terhadap keberdayaan petani karet. Peneliti selanjutnya disarankan untuk memasukkan variabel lain seperti kompetensi, motivasi, dan kemandirian penyuluh ketika melakukan kajian yang sejenis

5. Keberdayaan memberikan pengaruh yang signifikan hanya sebesar 2,77 persen terhadap tercapainya tujuan penyuluhan dan masih terdapat 97,22 persen. Disarankan kepada peneliti selanjutnya memasukkan variabel lain seperti kemandirian petani, faktor lingkungan yang ikut berpengaruh terhadap tercapainya tujuan penyuluhan yang perlu ditambahkan peneliti selanjutnya kedalam variabel penelitian.

\section{Daftar Pustaka}

Amru A. 2012. Analisis kesejahteraan rumah tangga pengrajin plasma di Desa Rimbo Makmur Kecamatan Tapung Hulu Kabupaten Kampar. [skripsi]. Pekanbaru (ID): Universitas Riau.

Ancok. A. 2002. Teknik Penyusunan Skala Pengukur.

Pusat Studi Kependudukan dan Kebijakan. Universitas Gadjah mada. Yogyakarta.

Asyiek Fauziah, 2014. Perilaku Komunikasi dan Keberdayaan Petani Wanita Agribisnis di Kawasan Pedesaan Provinsi Sumatera Selatan. Tesis dalam Pengijazahan Program Doktor Universiti Utara Malaysia. http://etd.uum.edu. my/4492/7/s92173 abstract.pdf [20-3-2017]

Badan Pusat Statistik Provinsi Riau. 2015. Rokan Hilir dalam Angka 2014. Riau.

Budiman H. 2012. Budidaya Karet Unggul. Pustaka Baru Press. Yogyakarta.

Departemen Pertanian, 2006. Undang-Undang Republik Indonesia Nomor 16 Tahun 2006 Tentang Sistem Penyuluhan Pertanian, Perikanan dan Kehutanan, Jakarta

Dinas Perkebunan Provinsi Riau, 2014. Rencana Strategis (Renstra) Dinas Perkebunan Provinsi Riau Tahun 2014 - 2019. Dinas Perkebunan, Pemerintah Provinsi Riau

Dinas Perkebunan Kabupaten Rokan Hilir. 2015. Data Perkebunan Kabupaten Rokan Hilir 2014. Pemerintah Kabupaten Rokan Hilir.

Dinas Perkebunan Provinsi Riau. 2015. Statistik Perkebunan Provinsi Riau 2014. Riau.

Ferdinand A. 2006. Metode Penelitian Manajemen:

Pedoman Penelitian Untuk Skripsi, Tesis dan

Disertasi Ilmu Manajemen. Semarang (ID): Universitas Diponegoro.

Hidayat, Syamsul B. 2001. Pemberdayaan Ekonomi Rakyat. Sebuah RekonstruksiKonsep Community Based Development (CBD). Pustaka Quantum. Jakarta.

Indraningsih K S, 2011. Pengaruh Penyuluhan Terhadap

Keputusan Petani Dalam Mengadopsi Inovasi

Teknologi Usahatani Terpadu. Jurnal Agro Ekonomika Vol. 29 No.1 Mei 2011. Pusat Kebijakan Ekonomi dan Sosial Pertanian. Bogor Kusnaini DK, Muljono P, Saleh A, 2015. Dinamika Kelompok Penerima CSR PLN Tarahan Lampung Selatan. Jurnal Penyuluhan Vol. 11 No.2, September 2015. IPB Bogor

Kusning, Sayeti AAS, Budihardjo K, 2011. Kajian Pendapatan Petani Karet dan Petani Kelapa Sawit di Kecamatan Pasir Penyu, Kabupaten 
Indra Giri Hulu, Provinsi Riau. http://dokumen. tips/data-analytics/kajian-pendapatan-petanikarethevea-brasiliensis-dan-petani-kelapasawitelaeis-guinensis-jacq-di-kecamatan-pasirpenyu-kabupaten-indragiri-hulu-provinsi-riau. html [21-3-2017]

Leuuwis. 2009. Komunikasi Untuk Inovasi Pedesaan. Kanisius: Yogyakarta.

Mardikanto T. 2009. Sistem Penyuluhan Pertanian. Surakarta: Sebelas Maret University Press. 2012. Pemberdayaan Masyarakat dalam Perspektif Kebijakan Publik. Alfabeta, Banddung Nachrowi D, Usman H. 2005. Penggunaan Teknik Ekonometrik. Rajawali pers. Jakarta.

Rosnita, Yulida R, Arifudin. 2012. Tingkat Keberdayaan Lembaga Keuangan Mikro Dalam Peningkatan Produksi Kelapa Sawit Di Provinsi Riau. Seminar Nasional Dan Rapat Tahunan (SEMIRATA) BKS-PTN Wilayah Barat Bidang Ilmu Pertanian Di Universitas Sumatera Utara (USU) Medan Pada Tanggal 3 April 2012.

Rosnita.2011.Keberdayaan petani melalui implementasi program pemberdayaan desa (ppd) dalam menanggulangi kemiskinan di provinsi riau (kasus program ppd di kabupaten rokan hulu). [disertasi]. Bandung (ID): Universitas Padjajaran.

Timbulus M V.G, Sondakh M L, Rumagit G A.J, 2016. Persepti Petani Terhadap Peran Penyuluh Pertanian Di Desa Rasi Kecamatan Ratahan Kabupaten Minahasa Tenggara. Jurnal Agri Sosioekonomi Unsrat Vol.12 No. 2A Juli 2016.

TKP3KPK.2004.DokumentasiStrategiPenanggulangan Kemiskinan Berbasis Pemberdayaan Masyarakat. Kementrian Koordinator Bidang Kesejahteraan Rakyat. Jakarta.

TKP3 KPK Provinsi Riau. 2006. Pedoman Umum Program Pemberdayaan Desa (PPD). Badan Pemberdayaan dan Perlindungan Masyarakat. Pemerintah Provinsi Riau.

Sadono Dwi, 2008. Pemberdayaan Petani: Paradigma Baru Penyuluhan Pertanian Di Indonesia. Jurnal Penyuluhan Maret 2008, Vol.4 No.1. IPB Bogor

Sangadji M. 2011. Strategi Penyuluhan di Kawasan Konservasi (Kasus Taman Nasional Kepulauan Togean). Abstrak, halaman 1. Jurnal Penyuluhan IPB. Bogor.

Slamet M, 2003. Slamet M. 2003. Membentuk Pola Perilaku Manusia Pembangunan. Editor: Adjat Sudradjat dan Ida Y ustina. IPB Press. Bogor. 